especially important, why and how they interpreted that doctrine in the ways that they did. But Klimke, rather than develop this valuable thinking and use it as the core of an important book, fritters away his energy displaying the various archival nuggets he has found. Behind this failure, and The Other Alliance's ultimate shortcoming, lies a philosophy of history which Klimke articulates in his book's penultimate paragraph:

Taking a more comprehensive, multidimensional perspective on the global sixties will help us escape the traditional front lines as well as fuel further research. Regardless of whether we judge the decade's legacies as positive or negative, a thorough investigation will keep alive its philosophical, artistic, cultural, and political richness as a significant, if at times contradictory, site of memory, and not allow the sixties to be turned into a site of partisan bickering or oblivion [244].

In short, Klimke has opted for a history which counts stones, and describes their colours. Sometimes the description of a stone and its immediate context may be sufficient for a geologist to estimate the stone's origin; and for an historian, conversant with a particular historical period, the mere presentation of historical facts may be enough to help gauge the social and political forces involved in creating an event. But Klimke wanted to understand the relationship between social movements in the U.S. and Germany, and understand the place of the sixties in the overall post-World War II history. This is quite impossible without an analysis of the real power relations of the time: who are the oppressors; who are the oppressed; what does oppression and resistance mean to the oppressed and the oppressor? Non-partisan history cannot answer these questions. Nor can it answer the questions Martin Klimke sets for himself in The Other Alliance.

$$
\begin{aligned}
& \text { David Barber } \\
& \text { University of Tennessee at Martin }
\end{aligned}
$$

\title{
Lars Schoultz, That Infernal Little Cuban Republic: The United States and the Cuban Revolution (University of North Carolina Press, 2009).
}

Lars Schoultz is a highly decorated American political scientist who has spent three decades writing about United States - Latin American relations. That Infernal Little Cuban Republic is his fifth monograph, the crowning achievement of a career spent teasing the ambiguities out of mountains of American political, diplomatic and intelligence files. At 745 pages, That Infernal Little Cuban Republic is one of the most ambitious and thoroughgoing histories of the Cuban-American relationship yet written. It is also the finest.

Schoultz's stated thesis is simple, powerful and well-rehearsed. Since the Spanish American War and arguably even earlier, most U.S. policy makers have 
approached Cuba with the hubris, ethnocentrism and benevolent condescension of any garden-variety imperial power. Their self-appointed mission — repeated ver batim from the era of William Howard Taft to that of George W. Bush - has been to "go down and lift those people up." Yet, for reasons understood by the colonized all over the globe, Cubans up to and including Fidel Castro have insisted that they be treated "as anyone would like to be treated by their neighbors that is, as equals and with respect" (553). The irresistible force of American paternalism has thus been colliding for over a century with the immovable object that is Cuban nationalism. The result, according to Schoultz, is a diplomatic staring contest of unequalled intensity, one that is mystifying to the world beyond the Straits of Florida.

Alongside this consensus view of Cuban-American relations, Schoultz offers two sub-theses that are as persuasive as they are novel, both of which challenge conventional wisdom directly. The first is that, contrary to the popular perception that American presidents have spent a good portion of every day since 1959 fussing about the Revolution and fuming about Castro, Cuba "disappeared from Washington's consciousness" in 1966, after LBJ passed the Cuban Adjustment Act (239). The structure of Schoultz's book, in which each presidential administration gets its own chapter, lends credence to this claim. "[]n 1970 President Nixon did not say 'Cuba' once in public," he writes (245). "Overall, the most striking feature of President Clinton's second-term policy was how thoroughly Cuba was ignored" (513). With the exception of the Kennedy administration — think Bay of Pigs, the Cuban Missile Crisis, Operation Mongoose, etc. - genuine U.S. foreign policy obsessions, from Vietnam to Afghanistan, have rendered Cuba a headline-grabbing but ultimately inconsequential diplomatic sideshow.

Schoultz's second important sub-thesis is also counter-intuitive. In contrast with the common perception that the Cuban-American relationship has always been inherently unstable, always a hair's breadth from bursting into open warfare, That Infernal Little Cuban Republic recounts in painstaking detail how the ceaseless war of words between Castro and his American adversaries has masked an evolving, carefully managed détente. "After one major miscalculation (the missile crisis)," Schoultz argues, "Cubans became exceptionally astute at determining the line they could not cross without triggering a revolution-ending reaction.... [B] oth sides learned to live without crossing the line." (555)

That Infernal Little Cuban Republic is a pleasure to read - lucid, authoritative and never dull. For me, the book bogged down a little on the minutiae of the embargo and American trade law as it has applied to Cuba over the years (the Trading With the Enemy Act, the Torricelli Act and Helms-Burton, etc.) but this is a minor criticism. Indeed, the case can be made that Schoultz has done students of American and Cuban policy a great favour in codifying for the first time the tortuous politics of Washington's fifty-year-old trade sanctions. Scholars 
of the Cuban-American relationship, and those familiar with its myriad theatrics, contradictions and absurdities, will chuckle at Schoultz's dry wit and his unforgiving eye for irony. "U.S.-Cuban relations did not improve after George Schultz became secretary of state in mid-1982," he notes. "A longtime Reagan supporter and reliable team player ... Schultz had been a perfectly respectable professor until a tragic moment of moral impairment led him to accept a deanship." (386)

Like all of us, Schoultz is hamstrung when it comes to archival sources. Because the Cuban government considers virtually everything that has happened since 1959 a matter of national security, Havana's archives are a closed shop. In the United States, similarly, the closer one gets to the present, the more archival files remain classified. Schoultz's treatment of the Eisenhower and Kennedy administrations has benefited greatly from recent declassifications; but by the time he has to grapple with Clinton- and Bush-era Cuba policies, he, like the rest of us, is mostly stuck with public documents and press clippings. Schoultz is such a masterful writer that a casual reader might not even notice this transition from private to public documents. But anyone who has had to deal first-hand with the archives on both sides of the Cuban-American divide cannot help but be impressed with Schoultz's ability to squeeze his story out of an ever-diminishing pool of documents.

It is perhaps a little unfair to conclude with the following question, yet it occurred to me repeatedly as I made my way through That Infernal Little Cuban Republic: why put this book out now? Schoultz is well aware of the pitfalls of prognosticating on the Castros' Revolution — he reminds us, for example, that Brian Latell, former CIA analyst and author of After Fidel (2005), began predicting Fidel Castro's overthrow in 1981. Today, however, Fidel is nearly 85 and retired; Raúl is about to turn 80; and the newly appointed Number Two man in the Cuban government, José Ramón Machado, is 80 himself. It is no longer a stretch, as it was in the 1970s when people first began talking about the "postCastro" future of Cuba, to imagine that we are on the cusp of change, that it might fall on President Obama's watch, and that, indeed, in purging their inner circle of long-time loyalists, as they did in 2009, the Castros are stage-managing it. That Infernal Little Cuban Republic concludes with George W. Bush's alreadyanachronistic "Commission for Assistance to a Free Cuba." Not even as perceptive a writer as Schoultz, it turns out, can keep up with the monthly and sometimes daily jolts that emanate from Havana and Washington.

All of which is to say simply this: When the dust finally does settle on the Castro era, and the Cuban and American people finally do find a way to coexist in peace and prosperity, let us hope that Mr. Schoultz will be around to produce another edition of his fine book, thus allowing himself the pleasure of tying off some of these endlessly fascinating loose ends.

Robert Wright Trent University 